\title{
ANALISIS STRUCTURAL EQUATION MODELLING PENDEKATAN PARTIAL LEAST SQUARE DAN PENGELOMPOKAN DENGAN FINITE MIXTURE PLS (FIMIX-PLS) (Studi Kasus: Kemiskinan Rumah Tangga di Indonesia 2017)
}

\author{
Esta Dewi Anggita $^{1}$, Abdul Hoyyi ${ }^{2}$, Agus Rusgiyono ${ }^{3}$ \\ 1,2,3 Departemen Statistika FSM Universitas Diponegoro \\ e-mail : estaanggita@gmail.com
}

\begin{abstract}
Poverty is a complex and multidimensional problem that links several dimensions. Statistical method that can explain the relationship between one latent variable with others is Structural Equation Modelling (SEM). The purpose of this study is to create a structural model of the relationship between education, health, economy and poverty in Indonesia in 2017 by using Structural Equation Modeling with Partial Least Square approach (SEM-PLS) based on predetermined indicators with the results of 11 valid indicators. Based on the model obtained, health has a significant positive effect on education, health and education have a significant positive effect on the economy and the economy has a significant negative effect on poverty. Segmentation based on the relationship of latent variables in structural models can be overcome by Finite Mixture Partial Least Square (FIMIX-PLS) so that it can identify poverty areas in each province in Indonesia with more homogeneous characteristics. The best segmentation result is number of segments $(\mathrm{K})=2$ obtained based on the criteria of AIC, BIC, CAIC and Normed Entropy (EN) with an EN value of 0.964 which means the quality of segment separation is very good. Papua and West Papua provinces form one segment in segment 2 , while 32 other provinces form one segment in segment 1.
\end{abstract}

Keywords: Poverty, Structural Equation Modelling, Partial Least Square, Finite Mixture, Segmentation.

\section{PENDAHULUAN}

Kemiskinan merupakan permasalahan yang fundamental karena kemiskinan merupakan indikator yang dapat digunakan untuk mengukur pencapaian pembangunan. Kemiskinan lebih sering dikaitkan dengan dimensi ekonomi karena dimensi inilah yang paling mudah diamati, diukur, dan diperbandingkan. Padahal kemiskinan adalah permasalahan yang kompleks dan multidimensional yang berkaitan juga dengan berbagai dimensi lain. Metode statistika yang dapat digunakan untuk menganalisis keterkaitan antar dimensi kompleks yang mempengaruhi kemiskinan di Indonesia adalah Structural Equation Modelling (SEM). SEM mempunyai kemampuan lebih dalam menyelesaikan permasalahan yang complicated yaitu mampu melakukan estimasi hubungan antar variabel yang bersifat multiple relationship dengan output berupa model pengukuran dari sejumlah indikator dan model struktural yang tersusun dari sejumlah konstruk (variabel laten). SEM berbasis komponen yaitu Partial Least Square (PLS) adalah metode analisis yang powerful karena pendugaan parameter pada Partial Least Square tidak mengasumsikan data harus dengan skala pengukuran tertentu, jumlah sampel tidak harus besar, dan tidak mengasumsikan data harus berdistribusi normal multivariat seperti Ordinary Least Square (OLS) (Ghozali, 2011).

Pengelompokan objek ke dalam beberapa kelompok dilakukan berdasarkan ukuran kemiripan atau ciri umum antar objek. Dalam pengelompokan sering ditemukan objek yang tidak bisa diukur secara langsung karena tidak mempunyai nilai kuantitatif. Objek tersebut disebut dengan variabel laten. Metode yang dapat digunakan untuk mengelompokan variabel laten berdasarkan variabel indikator adalah metode Finite Mixture Partial Least Square yang 
dikembangkan oleh Hahn et al. (2002) yang menghasilkan segmen dengan anggota yang lebih homogen berdasarkan hubungan antar variabel laten pada model persamaan struktural. Oleh karena itu, dapat diperoleh segmen-segmen wilayah di Indonesia berdasarkan hubungan variabel laten antara kesehatan, pendidikan, ekonomi, dan kemiskinan. Sehingga dapat digunakan untuk menerapkan program pengentasan kemiskinan dengan memperhatikan kecenderungan variabel yang berpengaruh paling besar terhadap kemiskinan pada masing-masing provinsi menurut kelompok segmen yang diperoleh.

\section{TINJAUAN PUSTAKA}

\subsection{Structural Equation Modelling (SEM)}

Structural Equation Modeling (SEM) merupakan generasi kedua metode analisis multivariat yang dapat digunakan untuk menggambarkan keterkaitan hubungan linier secara simultan antara variabel pengamatan (indikator) dan variabel yang tidak dapat diukur secara langsung (variabel laten). Terdapat dua tipe variabel laten dalam SEM yaitu variabel eksogen $(\eta)$ dan variabel endogen $(\bar{\zeta})$.

\subsection{Partial Least Square (PLS)}

Partial Least Square (PLS) adalah suatu metode alternatif untuk model persamaan struktural yaitu untuk menguji secara simultan hubungan antar konstruk laten dengan banyak indikator. PLS sering disebut sebagai soft modeling karena meniadakan asumsi-asumsi, seperti asumsi data tidak harus berdistribusi normal multivariat, tidak mengasumsikan data harus dengan pengukuran skala tertentu, dan jumlah sampel tidak harus besar (Hair et al, 2014). PLS dimaksudkan untuk tujuan prediksi (causal-perdictive analysis) dalam situasi kompleksitas yang tinggi dan dukungan teori yang rendah.

\subsection{Spesifikasi Model PLS}

Spesifikasi lengkap dari model jalur yang terdiri dari model struktural dan model pengukuran, model jalur dalam PLS terdiri dari tiga set hubungan:

(1) inner model yang menspesifikasikan hubungan antar variabel laten.

Persamaan inner model adalah:

$$
\eta=\mathbf{B} \eta+\Gamma \xi+\zeta
$$

(2) outer model yang menspesifikasikan hubungan antara variabel laten dengan indikator atau manifesnya. Blok dengan indikator refleksif dapat ditulis dengan persamaan sebagai
berikut: $\mathbf{x}=\lambda_{\mathrm{x}} \xi+\delta_{\mathrm{x}}$
$\mathbf{y}=\lambda_{y} \eta+\varepsilon_{y}$
$\mathbf{X}_{\mathbf{j k}}=\lambda_{\mathbf{j k}} \xi_{\mathbf{j}}+\delta_{\mathbf{j k}}$

Blok dengan indikator formatif dapat ditulis dengan persamaan sebagai berikut:

dengan:

$$
\xi=\pi_{\xi} \mathbf{X}+\delta_{\xi} \quad \eta=\pi_{\eta} \mathbf{y}+\varepsilon_{\eta} \quad \xi_{\mathbf{j}}=\pi_{\mathbf{j k}} \mathbf{X}_{\mathbf{j k}}+\delta_{\mathbf{j}}
$$

$\eta$ : vektor variabel laten endogen

$\xi$ : vektor variabel laten eksogen

B : koefisien matriks untuk variabel laten endogen

$\Gamma$ : koefisien matriks untuk variabel laten eksogen

$\zeta$ : kesalahan pengukuran variabel laten

$\mathbf{x}$ : indikator pada variabel laten eksogen

$\mathbf{y}$ : indikator pada variabel laten endogen

$\lambda_{\mathbf{x}}, \lambda_{\mathbf{y}}$ : matriks loading yang menggambarkan koefisien regresi sederhana

$\pi_{\xi}, \pi_{\eta}$ : koefisien regresi berganda dari variabel laten dan blok indikator

$\delta_{\xi}, \varepsilon_{\eta}$ : residual dari regresi 
(3) weight relation yang dapat menghitung skor variabel laten berdasarkan bagaimana inner model dan outer model dispesifikasi. Nilai kasus untuk setiap variabel laten diestimasi dalam PLS sebagai berikut:

$$
\begin{aligned}
& \xi_{\mathrm{j}}=\sum_{\mathrm{k}} \mathrm{w}_{\mathrm{jk}} \mathrm{X}_{\mathrm{jk}}, \text { untuk variabel eksogen } \\
& \eta_{\mathrm{j}}=\sum_{\mathrm{k}} \mathrm{w}_{\mathrm{jk}} \mathrm{Y}_{\mathrm{jk}}, \text { untuk variabel endogen }
\end{aligned}
$$

Dimana $w_{j k}$ adalah bobot yang digunakan untuk mengestimasi variabel laten sebagai kombinasi linier dari variabel manifesnya.

\subsection{Algoritma Model PLS}

Tahap 1: Tujuan pada tahap ini adalah untuk memperoleh estimasi skor variabel laten sebagai kombinasi linier $\left(\mathrm{Y}_{\mathrm{j}}\right)$ dari variabel manifes $\mathrm{X}_{\mathrm{jk}}$ dengan menghitung penimbang melalui proses iterasi.

\section{Tahap 1.1: Outside Approximation}

Tahap ini disebut juga tahap estimasi eksternal. Ide dasar dari tahap ini adalah mendapatkan sekumpulan bobot untuk mengestimasi sebuah variabel laten sebagai kombinasi linier dari variabel indikator melalui proses iterasi. Pada tahap ini proses iterasi dimulai dengan sebuah pendekatan awal untuk setiap variabel laten sebagai kombinasi linier (weighted agregate) dari setiap variabel manifesnya $Y_{j}=\sum_{k} \widetilde{w}_{j k} X_{j k}$

\section{Tahap 1.2: Inside Approximation}

Tahap ini disebut tahap estimasi internal. Tahap ini memperhatikan hubungan antara variabel laten dalam inner model untuk mendapatkan suatu pendekatan baru dari setiap variabel laten yang telah dihitung pada outside approximation sebagai agregat tertimbang dari variabel laten lainnya yang saling berdekatan. estimasi internal $Z_{j}$ dari variabel laten dirumuskan dengan:

$$
Z_{j}=\sum_{i \leftrightarrow j} e_{i j} Y_{i} \quad \text { dengan } e_{i j} \text { adalah inner weight. }
$$

Skema yang digunakan untuk menghitung inner weight $e_{i j}$ yaitu Path Scheme. Jika variabel laten $\mathrm{Y}_{\mathrm{i}}$ adalah prediktan dari variabel laten $\mathrm{Y}_{\mathrm{j}}$, maka inner weight sama dengan nilai korelasi antara $Y_{i}$ dan $Y_{j}$. Sedangkan untuk prediktor-prediktor $Y_{i}$ dari variabel laten $\mathrm{Y}_{\mathrm{j}}$, maka inner weight adalah koefisien regresi dari $\mathrm{Y}_{\mathrm{i}}$ dalam regresi berganda terhadap $\mathrm{Y}_{\mathrm{j}}$.

$$
e_{i j}=\left\{\begin{array}{c}
\operatorname{cor}\left(Y_{j}, Y_{i}\right), \text { untuk } Y_{j} \text { dan } Y_{i} \text { berdekatan } \\
\sum_{i} e_{i j} Y_{i}, \text { untuk } e_{i} \text { dalam regresi } Y_{j} \text { terhadap } Y_{i} \\
0, \text { untuk yang lainnya }
\end{array}\right\}
$$

\section{Tahap 1.3 Updating Outer Weight}

Ketika tahap inside approximation telah selesai, estimasi internal $Z_{j}$ harus dilihat kembali hubungannya terhadap indikator-indikatornya. Hal ini dilakukan dengan melakukan updating outer weight bergantung dengan blok indikator. Untuk hubungan formatif dapat dirumuskan dengan:

$$
\widehat{w}_{j k}=\left(X_{j k}^{T} X_{j k}\right)^{-1}\left(X_{j k}^{T} Z_{j}\right)
$$

\section{Tahap 1.4 Pemeriksaan Konvergensi}

Pada setiap tahap iterasi $S=1,2,3 \ldots$, konvergensi diperiksa dengan membandingkan outer weight pada tahap iterasi ke-S dengan nilai outer weight pada tahap ke-(S-1). Menurut Sanchez (2013) menyarankan batasan dengan $\left|\widetilde{w}_{j k}^{S-1}-\widetilde{w}_{j k}^{S}\right|<10^{-5}$ sebagai batas konvergensi. Jika telah konvergen, maka didapat nilai dugaan akhir variabel laten. $Y_{j}=\sum_{k} \widetilde{w}_{j k}^{n e w} X_{j k}$

\section{Tahap 2:}

Tahap kedua menduga estimasi koefisien jalur $\hat{\beta}_{j i}=\beta_{j i}$ untuk setiap inner model. 
Untuk koefisien jalur model struktural diduga dengan ordinary least square pada regresi berganda $Y_{j}$ dan $Y_{i}$ yang bersesuaian.

$\widehat{\boldsymbol{\beta}}_{j i}=\left(\boldsymbol{Y}_{i}^{\prime} \boldsymbol{Y}_{\boldsymbol{i}}\right)^{-1} \boldsymbol{Y}_{\boldsymbol{i}}{ }^{\prime} \boldsymbol{Y}_{j}$

\section{Tahap 3:}

Tahapan algoritma ini adalah menghitung koefisien loading. Koefisien loading diperoleh dengan menghitung korelasi antara variabel laten dengan masing-masing indikatornya. $\lambda_{j k}=\operatorname{cor}\left(X_{j k}, Y_{j}\right)$

\subsection{Evaluasi Model PLS}

a. Evaluasi Model Pengukuran

Pengujian indikator formatif dengan melihat nilai signifikansi bobot $\mathrm{w}_{\mathrm{jk}}$ dengan hipotesis:

$\mathrm{H}_{0}: w_{j k}=0$ (indikator tidak signifikan)

$\mathrm{H}_{1}: w_{j k} \neq 0$ (indikator signifikan)

Statistik Uji: $\quad \mathrm{t}_{\text {hitung }}=\frac{\widehat{w}_{j k}}{S E\left(\widehat{w}_{j k}\right)}$

Keterangan:

$\widehat{w}_{\mathrm{jk}}$ : bobot indikator ke-k dari variabel laten ke-j

$S E\left(\widehat{w}_{j k}\right)$ : standar error bootstrapping untuk bobot indikator

Dengan kriteria uji $\mathrm{H}_{0}$ ditolak jika $\mid \mathrm{t}$-hitung $\mid>\mathrm{t}_{\alpha / 2 \text {;n-1 }}$ dengan tingkat kepercayaan (1- $\left.\alpha\right)$

$100 \%$ yang berarti bahwa bobot setiap indikator adalah signifikan. Pengujian dapat

dilakukan setelah dilakukan bootstrapping.

b. Evaluasi Model Struktural

Nilai $\mathrm{R}^{2}$ ditentukan dengan persamaan sebagai berikut:

$\mathrm{R}^{2}=\frac{\mathrm{JKR}}{\mathrm{JKT}}=\frac{\mathrm{JKT}-\mathrm{JKG}}{\mathrm{JKT}}=1-\frac{\mathrm{JKG}}{\mathrm{JKT}}$

\subsection{Pengujian Hipotesis}

Pengujian hipotesis dilakukan dengan prosedur bootstrapping. Hipotesis yang digunakan adalah:

Hipotesis statistik untuk inner model:

$$
\begin{array}{llllll}
\mathrm{H}_{0} & : & \beta_{i}=0 \text { atau } & \mathrm{H}_{0} & : & \gamma_{i}=0 \\
\mathrm{H}_{1} & : & \beta_{i} \neq 0 \text { atau } & \mathrm{H}_{1} & : & \gamma_{i} \neq 0
\end{array}
$$

Statistik uji yang digunakan adalah uji t, dengan rumus sebagai berikut.

$t_{\text {hitung }}=\frac{\widehat{\beta}_{i}}{S E^{*}\left(\widehat{\beta}_{i}\right)}$, untuk uji terhadap inner model endogen-endogen

$t_{\text {hitung }}=\frac{\widehat{\gamma}_{i j}}{S E^{*}\left(\gamma_{i j}\right)}$, untuk uji terhadap inner model eksogen-endogen

Dengan kriteria uji $\mathrm{H}_{0}$ ditolak jika $\mid \mathrm{t}$-hitung $\mid>\mathrm{t}_{\alpha / 2 ; n-1}$ dengan tingkat kepercayaan (1- $\left.\alpha\right)$ $100 \%$ yang berarti bahwa koefisien jalur signifikan.

\subsection{Finite Mixture Partial Least Square (FIMIX-PLS)}

Estimasi FIMIX-PLS berdasarkan asumsi bahwa heterogenitas terjadi pada model struktural dengan mengasumsikan $\eta_{i}$ berdistribusi finite mixture dengan fungsi densitas normal multivariat bersayarat $\left.\mathrm{f}_{\mathrm{i}}\right|_{\mathrm{k}}($.$) dengan (\mathrm{K}<\infty)$ segmen:

$$
\boldsymbol{\eta}_{\boldsymbol{i}} \sim \sum_{k=1}^{K} \rho_{k} f_{i \mid k}\left(\boldsymbol{\eta}_{\boldsymbol{i}} \mid \boldsymbol{\xi}_{\boldsymbol{i}}, \mathbf{B}_{\boldsymbol{k}}, \boldsymbol{\Gamma}_{\boldsymbol{k}}, \boldsymbol{\Psi}_{\boldsymbol{k}}\right)
$$

Substitusi $f_{i \mid k}\left(\boldsymbol{\eta}_{\boldsymbol{i}} \mid \boldsymbol{\xi}_{\boldsymbol{i}}, \mathbf{B}_{\boldsymbol{k}}, \boldsymbol{\Gamma}_{\boldsymbol{k}}, \boldsymbol{\Psi}_{\boldsymbol{k}}\right)$ ke dalam distribusi normal multivariat menghasilkan persamaan berikut: 
$\eta_{\boldsymbol{i}} \sim \sum_{k=1}^{K} \rho_{k}\left[\frac{1}{(2 \pi)^{Q / 2}\left|\boldsymbol{\Psi}_{\boldsymbol{k}}\right|^{1 / 2}} \exp \left(-\frac{1}{2}\left(\mathbf{B}_{\boldsymbol{k}} \boldsymbol{\eta}_{\boldsymbol{i}}+\boldsymbol{\Gamma}_{\mathbf{k}} \xi_{\boldsymbol{i}}\right)^{\prime} \boldsymbol{\Psi}_{k}^{-1}\left(\mathbf{B}_{\boldsymbol{k}} \boldsymbol{\eta}_{\boldsymbol{i}}+\boldsymbol{\Gamma}_{\boldsymbol{k}} \xi_{i}\right)\right)\right]$

Dimana:

$\boldsymbol{\eta}_{\mathbf{i}}$ : vektor variabel endogen pada inner model $(i=1,2, \ldots \mathrm{I})$

$\xi_{\mathbf{i}}$ : vektor variabel eksogen pada inner model $(i=1,2, \ldots \mathrm{I})$

$\rho_{k}$ : proporsi mixing kelas laten $\mathrm{k}$, dimana $\rho_{k}>0$ dan $\sum_{k=1}^{K} \rho_{k}=1$

$\mathbf{B}_{\mathbf{k}}$ : matriks koefisien jalur pada inner model untuk kelas laten $\mathrm{k}$ yang menunjukkan hubungan antar variabel laten endogen berukuran $(\mathrm{Q} \times \mathrm{Q})$

$\Gamma_{\mathbf{k}}$ : matriks koefisien jalur pada inner model untuk kelas laten $\mathrm{k}$ yang menunjukkan hubungan antara variabel laten eksogen dan endogen berukuran $(\mathrm{Q} \times \mathrm{P})$

$\Psi_{\mathbf{k}}$ : matriks berukuran $(\mathrm{Q} \times \mathrm{Q})$ untuk kelas laten $\mathrm{k}$ yang mengandung varians untuk setiap regresi dari inner model

$\mathrm{i}$ : kasus / observasi dengan $\mathrm{i}=1,2, \ldots \mathrm{I}$

$\mathrm{k}$ : kelas atau segmen dengan $\mathrm{k}=1,2,3, \ldots, K$

$$
\begin{aligned}
& \text { // initial E-step } \\
& \text { Menentukan nilai awal random untuk } \mathrm{P}_{\mathrm{ik}} \text {, menentukan nilai } \mathrm{S} \text {, } \\
& 0<\mathrm{S}<1 \text {, menentukan last } \ln L \\
& \text { repeat do } \\
& \text { begin } \\
& \text { // M-step } \\
& \rho_{k}=\frac{\sum_{i=1}^{I} P_{i k}}{I} \forall \mathrm{k} \\
& \text { Menentukan } B_{k}, \Gamma_{k}, \Psi_{k}, \forall \mathrm{k} \\
& \text { Menghitung current } \mathrm{Ln} L \\
& \Delta=\text { current } \operatorname{Ln} L-\text { last } \ln L \\
& / / E \text {-step } \\
& \text { jika } \Delta \geq \mathrm{S} \text { maka hitung } \\
& \mathrm{P}_{i k}^{*}=\frac{\rho_{k}^{*} f_{i \mid k}\left(\eta_{i} \mid \xi_{i,} B_{k}^{*}, \Gamma_{k}^{*}, \Psi_{k}^{*}\right)}{\sum_{k=1}^{K} \rho_{k}^{*} f_{i \mid k}\left(\eta_{i} \mid \xi_{i,} B_{k}^{*}, \Gamma_{k}^{*}, \Psi_{k}^{*}\right)} \\
& \text { last } \ln L=\text { current } \operatorname{Ln} L \\
& \text { end } \\
& \text { end } \\
& \text { until } \Delta<\mathrm{S}
\end{aligned}
$$

\section{Gambar 1. Algoritma FIMIX PLS}

\subsection{Kriteria Pemilihan Segmen}

Untuk menentukan jumlah segmen terbaik $(\mathrm{K})$, peneliti dapat membandingkan nilai kriteria seperti Akaike Information Criterion $\left(\mathrm{AIC}_{\mathrm{k}}\right)$, Consistent AIC $\left(\mathrm{CAIC}_{\mathrm{k}}\right)$ dan Bayesian Information Criterion $\left(\mathrm{BIC}_{\mathrm{k}}\right.$ ) (Ringle, 2006). Rumus yang digunakan untuk menghitung kriteria AIC, CAIC, dan BIC adalah sebagai berikut:

$$
A I C_{K}=-2 \ln L+c N_{K}
$$

Dimana $c=2$ adalah konstan dan $N_{k}$ adalah jumlah parameter bebas

Dimana $c=\ln I$

$$
B I C_{K}=-2 \ln L+\ln I N_{K}
$$

Dimana $\mathrm{c}=(\ln (I)+1)$

$$
\text { CAIC }_{K}=-2 \ln L+(\ln (I)+1) N_{K}
$$


dengan:

$$
E N_{K}=1-\frac{\left[\sum_{i=1}^{I} \sum_{k=1}^{K}-P_{i k} \ln \left(P_{i k}\right)\right]}{I \ln K}
$$

$\mathrm{EN}_{\mathrm{k}}$ : Normal Entrophy, ukuran relatif antara 0-1

$P_{i k}$ : Peluang observasi ke-i pada kelas ke-k

$\mathrm{k}$ : kelas atau segmen dengan $\mathrm{k}=1,2, \ldots, \mathrm{K}$

i : observasi ke-i dengan $\mathrm{i}=1,2, \ldots, \mathrm{I}$

\section{METODE PENELITIAN}

\subsection{Data Penelitian}

Data yang digunakan dalam penelitian ini merupakan data sekunder mengenai dimensi kesehatan, pendidikan, ekonomi, dan kemiskinan di Indonesia pada tahun 2017. Data memiliki 34 observasi yang mewakili masing-masing Provinsi di Indonesia. Sumber data berasal dari publikasi online pada website resmi Badan Pusat Statistik (BPS) berdasarkan hasil survei sosial ekonomi nasional.

\subsection{Variabel dan Indikator Penelitian}

Variabel Penelitian yang digunakan terdiri atas empat variabel laten yang terbagi menjadi variabel laten eksogen dan variabel laten endogen yang masing-masing diukur dengan indikator-indikator yang dibangun berdasarkan teori konseptual, penelitian sebelumnya dan review literatur dengan unit observasi sebanyak 34 Provinsi di Indonesia.

$\begin{array}{lll}\text { Kesehatan } & \text { X11 } & \text { Angka Harapan Hidup (AHH) } \\ & \text { X12 } & \text { Persentase RT yang menggunakan sumber air minum layak } \\ \text { Pendidikan } & \text { X13 } & \text { Persentase penolong kelahiran oleh tenaga kesehatan } \\ & \text { Y11 } & \text { Angka Melek Huruf (AMH) } \\ & \text { Y12 } & \text { Angka Partisipasi Murni (APM) SMA/Sederajat } \\ \text { Ekonomi } & \text { Y13 } & \text { Angka Partisipasi Sekolah (APS) } \\ & \text { Y21 } & \text { Persentase RT yang menggunakan listrik } \\ & \text { Y22 } & \text { Proporsi individu yang memiliki telepon genggam } \\ \text { Kemiskinan } & \text { Y23 } & \text { Persentase penduduk yang bekerja di sektor formal } \\ & \text { Y31 } & \text { Persentase penduduk miskin (P0) } \\ & \text { Y32 } & \text { Indeks kedalaman kemiskinan (P1) } \\ & \text { Y33 } & \text { Indeks keparahan kemiskinan (P2) }\end{array}$


Variabel-variabel laten dan indikator yang digunakan digambarkan dalam kerangka konseptual sebagai berikut:

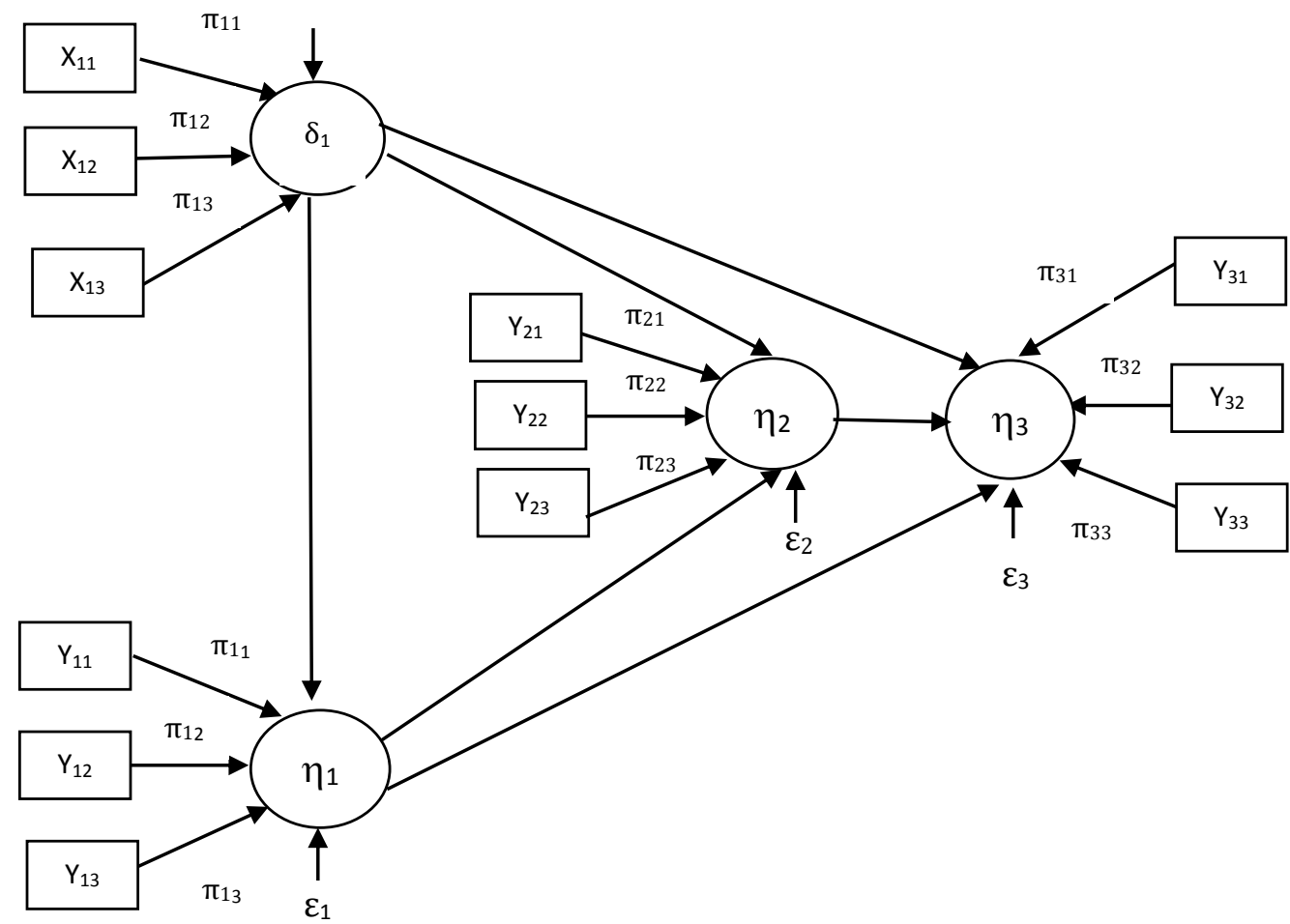

\subsection{Tahapan Analisis Data}

Gambar 2. Kerangka Teori Penelitian

Tahapan analisis yang dilakukan dalam penelitian ini adalah sebagai berikut:

1. Melakukan analisis menggunakan metode Structural Equation Modeling Partial Least Square (SEM-PLS)

a. Melakukan telaah pustaka dan kajian teori.

b. Konseptualisasi model meliputi merancang model pengukuran (outer model) dan model struktural (inner model).

c. Mengkontruksi diagram jalur (path diagram) yang menjelaskan pola hubungan antara variabel laten dan indikatornya atau menunjukkan hubungan jalur hubungan kausal antar variabel eksogen dan endogen.

d. Mengkonversi diagram jalur ke dalam persamaan.

e. Mengestimasi parameter model.

f. Mengevaluasi (outer model) atau model pengukuran dan dilanjutkan dengan mengevaluasi (inner model) atau model struktural untuk mendapatkan parameter model yang signifikan. Apabila terdapat parameter model yang tidak signifikan baik pada model pengukuran maupun struktural maka dilakukan proses trimming sehingga mendapatkan parameter model yang signifikan.

g. Melakukan pengujian hipotesis menggunakan metode resampling bootstrap.

2. Melakukan pengelompokan menggunakan metode Finite Mixture Partial Least Square (FIMIX-PLS).

3. Interpretasi dan kesimpulan. 


\section{HASIL DAN PEMBAHASAN}

\subsection{Analisis Structural Equation Modelling Partial Least Square}

Model struktur kemiskinan yang dibentuk berdasarkan indikator dan hubungan jalur yang signifikan terbentuk 11 indikator yang signifikan dan 4 hubungan jalur yang signifikan

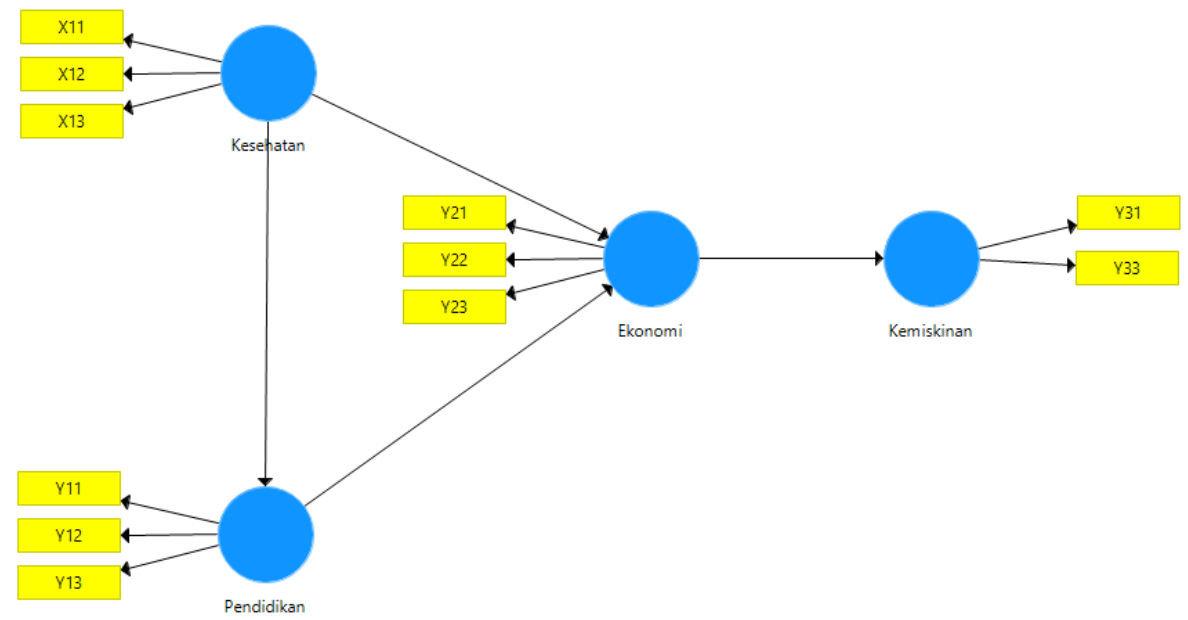

Gambar 2. Konseptualisasi model akhir

\section{Evaluasi Model Pengukuran}

Evaluasi model pengukuran pada indikator formatif dapat dilihat pada pengujian outer weight setiap indikator dan outer loading dengan prosedur bootstrapping untuk menilai signifikansinya. Uji signifikansi outer weight dapat dilihat pada Tabel 1.

Tabel 1. Nilai Outer Weights Variabel Laten

\begin{tabular}{cccccc}
\hline $\begin{array}{c}\text { Variabel } \\
\text { Laten }\end{array}$ & Indikator & $\begin{array}{c}\text { Nilai } \\
\text { Outer Weights }\end{array}$ & t-statistik & P-Value & Keterangan \\
\hline \multirow{3}{*}{ Kesehatan } & $\mathrm{X}_{11}$ & 0.526 & 6.311 & 0.000 & Signifikan \\
& $\mathrm{X}_{12}$ & 0.344 & 5.437 & 0.000 & Signifikan \\
& $\mathrm{X}_{13}$ & 0.354 & 6.385 & 0.000 & Signifikan \\
\hline \multirow{3}{*}{ Pendidikan } & $\mathrm{Y}_{11}$ & 0.388 & 2.274 & 0.023 & Signifikan \\
& $\mathrm{Y}_{12}$ & 0.336 & 2.640 & 0.008 & Signifikan \\
& $\mathrm{Y}_{13}$ & 0.396 & 3.669 & 0.000 & Signifikan \\
\hline \multirow{3}{*}{ Ekonomi } & $\mathrm{Y}_{21}$ & 0.410 & 7.616 & 0.000 & Signifikan \\
& $\mathrm{Y}_{22}$ & 0.385 & 13.685 & 0.000 & Signifikan \\
& $\mathrm{Y}_{23}$ & 0.339 & 9.686 & 0.000 & Signifikan \\
\hline \multirow{3}{*}{ Kemiskinan } & $\mathrm{Y}_{31}$ & 0.556 & 15.084 & 0.000 & Signifikan \\
& $\mathrm{Y}_{33}$ & 0.470 & 15.920 & 0.000 & Signifikan \\
\hline
\end{tabular}




\section{Evaluasi Model Struktural (inner model)}

Evaluasi model struktural pada SEM-PLS dilakukan dengan melihat kebaikan model struktural yang diukur dengan nilai koefisien determinasi $\mathrm{R}^{2}$ untuk setiap variabel laten endogen sebagai kekuatan prediksi dari model struktural. Diperoleh nilai $\mathrm{R}^{2}$ sebagai berikut:

Tabel 2. Nilai Koefisien Determinasi $\mathrm{R}^{2}$ Variabel Laten Endogen

\begin{tabular}{lc}
\hline Variabel Laten Endogen & $\mathrm{R}^{2}$ \\
\hline Pendidikan $\left(\eta_{1}\right)$ & 0.161 \\
Ekonomi $\left(\eta_{2}\right)$ & 0.697 \\
Kemiskinan $\left(\eta_{3}\right)$ & 0.557 \\
\hline
\end{tabular}

Evaluasi model struktural pada SEM-PLS juga dilakukan dengan melihat koefisien parameter jalur (path coefficients) antar variabel laten.

Tabel 3. Uji Koefisien Jalur antar Variabel Laten (Inner Model)

\begin{tabular}{lccccc}
\hline \multicolumn{1}{c}{ Inner Model } & $\begin{array}{c}\text { Koefisien } \\
\text { Jalur }\end{array}$ & $\begin{array}{c}\text { Estimasi } \\
\text { Koefisien } \\
\text { Jalur }\end{array}$ & t-hitung & P-Value & Keterangan \\
\hline Kesehatan -> Pendidikan & $\gamma_{11}$ & 0.402 & 2.892 & 0.004 & Signifikan \\
Kesehatan -> Ekonomi & $\gamma_{21}$ & 0.493 & 3.852 & 0.000 & Signifikan \\
Pendidikan -> Ekonomi & $\beta_{21}$ & 0.504 & 2.827 & 0.005 & Signifikan \\
Ekonomi -> Kemiskinan & $\beta_{32}$ & -0.747 & 7.593 & 0.000 & Signifikan \\
\hline
\end{tabular}

1. Model struktural (inner model) pengaruh kesehatan terhadap pendidikan

$\eta_{1}=\gamma_{11} \xi_{1}+\zeta_{1}$

$\eta_{1}=0.402 \xi_{1}+\zeta_{1}$

2. Model struktural (inner model) pengaruh kesehatan dan pendidikan terhadap ekonomi.

$\eta_{2}=\beta_{21} \eta_{1}+\gamma_{21} \xi_{1}+\zeta_{2}$

$\eta_{2}=0.504 \eta_{1}+0.493 \xi_{1}+\zeta_{2}$

3. Model struktural (inner model) pengaruh kesehatan, Pendidikan dan ekonomi terhadap kemiskinan.

$\eta_{3}=\beta_{32} \eta_{2}+\zeta_{3}$

$\eta_{3}=-0.747 \eta_{2}+\zeta_{3}$

\subsection{Analisis Pengelompokan dengan Finite Mixture Partial Least Square}

Hasil yang diperoleh berdasarkan analisis pada FIMIX-PLS adalah terbentuknya jumlah kelompok berdasarkan kriteria yang telah ditentukan, yaitu nilai AIC, BIC, CAIC, dan EN (Normed Entropy).

Tabel 4. Kriteria AIC, BIC, CAIC, dan EN untuk K=2,3,4,5,6

\begin{tabular}{cccccc}
\hline K & $\ln L$ & AIC & BIC & CAIC & EN \\
\hline 2 & -85.442 & 200.883 & 223.778 & 238.778 & 0.964 \\
3 & -73.754 & 193.507 & 228.613 & 251.613 & 0.819 \\
4 & -59.402 & 180.805 & 228.122 & 259.122 & 0.868 \\
5 & -43.163 & 164.325 & 223.853 & 262.853 & 0.948 \\
6 & -37.346 & 168.693 & 240.432 & 287.432 & 0.892 \\
\hline
\end{tabular}

Berdasarkan Tabel 4 diperoleh perbandingan untuk $\mathrm{k}=2,3,4,5$, dan 6 . Pada $\mathrm{k}=2$ nilai BIC, CAIC memiliki nilai yang terkecil dan memiliki nilai EN yang tertinggi sebesar 0.964. Hal ini mengindikasikan bahwa jumlah kelompok terbaik yang terbentuk adalah 
2, walaupun nilai AIC menunjukkan nilai yang bertolak belakang dengan BIC dan CAIC. Pengelompokan diperoleh berdasarkan nilai masing-masing probabilitas keanggotaan segmen. Pada jumlah kelompok 2, ukuran segmen (segment size) untuk kelompok 1 adalah sebesar 0.934 atau 93.4\% dari jumlah Provinsi di Indonesia. Kelompok 2 memiliki ukuran segmen (segment size) sebesar 0.066 atau 6.6\% dari jumlah Provinsi di Indonesia.

Tabel 5. Ukuran Segmen (segment size)

\begin{tabular}{lcc}
\hline & Segmen 1 & Segmen 2 \\
\hline$\%$ & 0.934 & 0.066 \\
\hline
\end{tabular}

\section{KESIMPULAN}

Berdasarkan hasil pembahasan terdapat 11 indikator yang signifikan dalam struktur model kemiskinan rumah tangga di Indonesia yaitu Angka Harapan hidup (AHH), Persentase rumah tangga yang menggunakan sumber air minum layak, Persentase penolong kelahiran oleh tenaga kesehatan, Angka Melek Huruf (AMH), Angka Partisipasi Murni SMA/Sederajat (APM), Angka Partisipasi Sekolah (APS), Persentase rumah tangga yang menggunakan listrik, Proporsi individu yang memiliki telepon genggam, Persentase penduduk yang bekerja di sektor formal, Persentase penduduk miskin (P0) dan Indeks keparahan kemiskinan (P2) yang berarti bahwa setiap indikator mampu menjelaskan variabel latennya. Pada model persamaan struktural terdapat 4 jalur yang signifikan, yaitu pengaruh kesehatan terhadap pendidikan, pengaruh kesahatan dan pendidikan terhadap ekonomi dan pengaruh ekonomi terhadap kemiskinan. Pengelompokan yang terbentuk dengan FIMIX-PLS berdasarkan kriteria AIC, BIC, CAIC dan EN diperoleh hasil terbaik yaitu 2 segmen yang terbentuk dari 34 Provinsi di Indonesia. Provinsi Papua dan Papua Barat membentuk satu segmen pada segmen dua, sedangkan 32 Provinsi lainnya membentuk satu segmen pada segmen satu.

\section{DAFTAR PUSTAKA}

[BPS]. Badan Pusat Statistik. 2018. Indikator Tujuan Pembangunan Berkelanjutan (TPB) Indonesia 2018. Jakarta: Badan Pusat Statistik.

Bollen, K. A. 1989. Structural Equations with Latent Variable. New York : John Wiley \& Sons .

C. M Ringle, Sven Wende, Alexander Will. 2010. Finite Mixture Partial Least Squares Analysis: Methodology and Numerical Examples.

Chin, W. W. 1998. The Partial Least Squares Approach to Structural Equation Modelling. Lawrence Erlbaum Associates .

Ghozali, I \& Latan, H. 2014. Partial Least Squares Konsep, Metode dan Aplikasi Menggunakan Program WarpPLS 4.0. Semarang: Badan Penerbit Universitas Diponegoro

Ghozali, I. 2011. Structural Equation Modelling Metode Alternatif dengan Partial Least Square. Semarang: Badan Penerbit Universitas Diponegoro.

Hahn, C., Johnson, M. D., Herrmann, A., Huber, F. 2002. Capturing Customer Heterogeneity Using A Finite Mixture PLS Approach. Schmalenbach Business Review, Vol. 54, 243-269.

Hair, J. F., Hult, G. T., Ringle, C. M., Sarstedt, M. 2014. A Primer on Partial Least Squares Structural Equation Modeling (PLS-SEM). SAGE Publications Ltd California

Jedidi, K., Jagpal, H. S., DeSarbo, W. S. 1997. Finite-Mixture Structural Equation Models for Response-Based Segmentation and Unobserved Heterogeneity. Institute for Operations Research and Management Science, Vol. 16, No. 01, 39-59. 
Ringle, C. M. 2006. Segmentation for Path Models and Unobserved Heterogeneity: The Finite Mixture Partial Least Squares Approach. Research Papers on Marketing and Retailing University of Hamburg.

Sanchez, G. (2013). PLS Path Modelling with R. Berkeley: Trowchez Editions. 